\title{
Pengembangan Kuliah Eksperimen Fisika dengan Teknologi Multimedia
}

\author{
Okimustava $^{1)}$, Ishafit ${ }^{1)}$, Nanang suwondo1), Rachmad Resmiyanto ${ }^{1)}$, Apik Rusdiarna Indra \\ Praja $^{2)}$ \\ I) Program Studi Pendidikan Fisika, Universitas Ahmad Dahlan, \\ Kampus III, J1. Prof. Dr. Soepomo, SH, Yogyakarta 55 I64 Indonesia \\ Surat-e: omustava@yahoo.co.id \\ 2) Program Studi Fisika Metrologi dan Elektronika Instrumentasi, Universitas Ahmad Dahlan, \\ Kampus III, J1. Prof. Dr. Soepomo, SH, Yogyakarta 55164 Indonesia
}

\begin{abstract}
Penelitian tentang pembelajaran berbasis lesson study untuk mata kuliah eksperimen fisika yang bertujuan untuk meningkatkan proses pembelajaran eksperimen fisika dengan dua jenis media instruksional berbasis teknologi multimedia, yaitu Video Based Laboratory (VBL) dan Simulation Based Laboratory (SBL). Lesson study merupakan kegiatan pembelajaran dengan kegiatan perencanaan (plan), implementasi pembelajaran (do) dan observasi serta refleksi (see) terhadap perencanaan dan implementasi pembelajaran. Topik eksperimen yang diberikan adalah Efek Fotolistrik, Watak Lampu Pijar, Gerak Harmonik Sederhana dan Verifkasi Hukum Kekekalan Momentum. Evaluasi kemampuan mahasiswa setelah pembelajaran meliputi evaluasi kongitif dengan tes konseptual tentang penguasaan materi fisika dan tes essay tentang kemampan analisis data eksperimental fisika, dan evaluasi keterampilan kerja ilmiah dengan membuat makalah dan poster ilmiah dari topik eksperimen yang dilakukan. Hasil penelitian bahwa pembelajaran berbasis lesson study pada mata kuliah eksperimen fisika menggunakan VBL dan SBL dapat meningkatkan kemampuan konseptual dan keterampilan mahasiswa.
\end{abstract}

Kata kunci: eksperimen fisika, teknologi multimedia, lesson study

\section{Pendahuluan}

Sebagian besar pembicaraan tentang pendidikan terutama tertuju pada bagaimana upaya untuk menemukan cara yang terbaik guna mencapai pendidikan yang bermutu dalam rangka menciptakan sumber daya manusia yang handal, baik dalam bidang akademis, sosio-personal, maupun vokasional.

Salah satu masalah pendidikan yang belakangan ini menarik untuk diperbincangkan yaitu tentang Lesson Study, yang muncul sebagai salah satu alternatif untuk mengatasi masalah praktik pembelajaran yang selama ini dipandang kurang efektif.

Tujuan pembelajaran fisika antara lain memahami dan mengaplikasikan metode inkuiri sainstifik dan desain teknik untuk penelitian, penyelesaian masalah, dan kemampuan analisis; memahami fakta dan konsep terpadu dalam fisika; dan memahami hubungan antara sains (fisika), teknologi, dan masyarakat. Pengalaman laborartorium melalui eksperimen fisika yang dilengkapi berbagai bentuk teknik visualisasi gejala (dengan teknik demonstrasi, simulasi, model, grafik real time, dan video) dapat memberikan kesempatan pada mahasiswa tidak hanya dalam pengembangan pemahaman terhadap konsep fisika, tetapi juga pengembangan pada keterampilan penelitian saintifik dan inkuiri. Menggabungkan teknik visualisasi ke dalam pengalaman laboratorium atau eksperimen akan memberi kesempatan pada mahasiswa untuk terlibat dalam proses aktif pada pembelajaran fisika sebagai standar pembelajaran (Gamboa, et al, 1999).

Kemajuan teknologi telah menghasilkan peningkatan penggunaan komputer dalam pembelajaran fisika dalam dekade terakhir ini. Komputer dapat mengenalkan dan menguatkan konsep melalui variasi bentuk latihan, praktek, tutorial. Apabila dihubungkan dengan beragam perangkat interfacing, komputer dapat digunakan untuk mengambil 
dan mengalisis berbagai jenis data dalam kegiatan laboratorium. Komputer juga dapat menyediakan tenik visualisasi, model gejala fisika atau eksperimen, dan dapat menggantikan peralatan eksperimen yang relatif mahal, dan eksperimen yang membahayakan seperti eksperimen pencacahan radiasi (Redish, 1993).

Oleh karena itu dalam penelitian ini akan dilakukan pengembangan proses pembelajaran eksperimen fisika dengan dua jenis media instruksional berbasis teknologi multimedia, yaitu Video Based Laboratory (VBL), dan Simulation Based Laboratory (SBL) berbasiskan lesson study. Dengan media ini mahasiswa dapat melakukan kegiatan hand-on dan mind-on experiment, sehingga dapat mengembangkan pemahaman konseptual dan keterampilan penelitian saintifik.

\section{Landasan Teori}

\section{Lesson Study}

Lesson study merupakan suatu kegiatan yang dilakukan oleh Guru dengan saling bekerjasama merencanakan kegiatan untuk meningkatkan kualitas pembelajaran yang dilakukan Guru dan aktivitas belajar siswa, serta akan menjadikan Guru yang profesional dengan desain pelaksanaan yang baik (Mustikasari, 2008). Lesson study pertama kali dikembangkan di Jepang oleh Makoto Yoshida sebagai bagian dari pengembangan profesi berbasis sekolah. Yoshida dalam Yusak (2007) menyebutkan tiga bagian utama dari lesson study adalah bagian pertama, yaitu identifikasi tema penelitian (research theme), bagian kedua pelaksanaan sejumlah research lesson yang akan mengeksplorasi reseach theme, dan bagian ketiga adalah refleksi proses pelaksanaan lesson study.

Slamet Mulyana (2007) dalam Sudrajat (2008) menyebutkan tahapan lesson study terdiri atas 4 bagian yaitu plan (perencanaan), do (pelaksanaan), check (refleksi) dan act (tindak lanjut). Meskipun melakukan pembagian tahapan yang berbeda, hal yang dilakukan oleh tim lesson study sebenarnya adalah sama yaitu di tahap perencanaan, tim menyusun RPP yang diawali dengan analisis permasalahan yang dihadapi dalam pembelajaran, kemudian pada tahap do, seorang dosen melaksanakan proses pembelajaran sesuai dengan RPP yang telah disusun bersama dan pelaksanaan observasi atau pengamatan oleh dosen lain. Lalu di tahap check (refleksi), para observer mengemukakan pendapat, analisis serta saran tentang pelaksanaan pembelajaran, dan hasil refleksi ini merupakan umpan balik yang sangat penting untuk memperbaiki RPP serta proses pembelajaran selanjutnya. Pada tahap tindak lanjut (act), dilakukan perbaikan RPP sesuai dengan hasil refleksi
Tim lesson study Program Studi Pendidikan Fisika, mengadakan plan yang dilaksanakan sebelum pelaksanaan lesson study di semester V. Adapun topik-topik yang dibahas antara lain masalah yang akan menjadi fokus pelajaran; cara memulai pelajaran, pertanyaan utama yang akan diberikan untuk memacu berfikir mahasiswa; antisipasi jawaban mahasiswa dan respon dosen, perangkat pembelajaran; hand out, pengaturan dan pemanfaatan media pembelajaran; kemajuan, alur dan keterpaduan pelajaran; cara mengakhiri pelajaran serta evaluasi. Hasil dari Plan ini adalah berupa SAP dan media yang akan digunakan. Tahap selanjutnya setelah Plan adalah Do pada pembelajaran Eksperimen Fisika semester $\mathrm{V}$ dilakukan oleh seorang dosen dan beberapa anggota tim lain yang berperan sebagai observer. Setelah proses pembelajaran selesai, dilakukan refleksi dan pengamat merefleksi serta membahas pelaksanaan Do. Pada tahap refleksi yang dilaksanakan setiap akhir $D o$, dilengkapi dengan notulen dan penasehat. Hasil refleksi ini dijadikan masukan dalam penyempurnaan Plan selanjutnya.

\section{Simulation Based Laboratory (SBL)}

Laboratorium virtual didefinisikan sebagai lingkungan yang interaktif untuk menciptakan dan melakukan eksperimen simulasi: taman bermain untuk bereksperimen. Ini terdiri dari domain dependent program simulasi, unit eksperimental disebut objek yang mencakup file data, alat yang beroperasi pada benda-benda, dan buku referensi (Jaya dan Haryoko, 2010).

Simulasi-simulasi interaktif PhET merupakan gambar bergerak (animasi), interaktif dan dibuat seperti layaknya permainan dimana siswa dapat belajar dengan melakukan eksplorasi. Simulasi-simulasi tersebut menekankan korespondensi antara fenomena nyata dan simulasi komputer kemudian menyajikannya dalam model-model konseptual fisis yang mudah dimengerti oleh para mahasiswa.

Simulasi PhET terdiri atas objek-objek yang abstrak, seperti atom, elektron, foton, dan medan listrik. Mahasiswa dapat melakukan interaksi melalui gambar dan kontrolkontrol intuitif yang di dalamnya memuat klik dan seret, saklar geser dan tombol-tombol atau memasukkan suatu data. Kemudian saat itu juga akibat dari interaksi yang dilakukan akan segera terlihat. Dengan animasi yang disajikan para siswa dapat menyelidiki sebab dan akibat pada fenomena yang disajikan (Resmiyanto, 2009). 


\section{Video Based Laboratory (VBL)}

Video Based Laboratory (VBL) merupakan salah satu media pembelajaran berbentuk software edukasi berbasis analisis video yang dapat diterapkan dalam kegiatan belajar mengajar (KBM) di kelas. Khususnya untuk mata pelajaran fisika pada topik pembelajaran Hukum Kekekalan Momentum dan Gerak Harmonik Sederhana. Salah satu nama software berbasis VBL adalah "Tracker". Software ini bersifat freeware yang dapat di-download secara gratis. Hal ini akan memudahkan siapa saja yang ingin memanfaatkan software tersebut. (Prasetyo, 2012).

\section{Metode Penelitian}

Subjek penelitian ini adalah mahasiswa semester 5 prodi Pendidikan Fisika FKIP Universitas Ahmad Dahlan. Objek penelitian adalah pengembangan proses pembelajaran eksperimen fisika dilihat pada aspek penguasaan pengetahuan koseptual, sikap, dan keterampilan mahasiswa.

Desain penelitian terdiri dari empat siklus, setiap siklusnya mengandung kegiatan perencanaan (plan), implementasi pembelajaran (do) dan observasi serta refleksi (see). Materi dan perangkat eksperimen fisika untuk setiap siklusnya ditunjukan pada Tabel I.

Tabel I. Materi dan Perangkat Eksperimen Fisika

\begin{tabular}{|c|c|c|c|c|}
\hline No & Topik & Tujuan & Media & Equipment \\
\hline I & $\begin{array}{l}\text { Efek } \\
\text { Fotolistrik }\end{array}$ & $\begin{array}{l}\text { Penentuan } \\
\text { Konstanta } \\
\text { Planck }\end{array}$ & $\begin{array}{l}\text { Software } \\
\text { Simulasi } \\
\text { Fisika } \\
\text { PhET }\end{array}$ & $\begin{array}{l}\text { Komputer } \\
\text { (SBL) } \\
\text { dengan } \\
\text { Spreadsheet }\end{array}$ \\
\hline 2 & $\begin{array}{l}\text { Watak } \\
\text { Lampu Pijar }\end{array}$ & $\begin{array}{l}\text { Menentukan } \\
\text { watak } \\
\text { lampu pijar }\end{array}$ & $\begin{array}{l}\text { Software } \\
\text { Simulasi } \\
\text { Fisika } \\
\text { PhET }\end{array}$ & $\begin{array}{l}\text { Komputer } \\
\text { (SBL) } \\
\text { dengan } \\
\text { Spreadsheet }\end{array}$ \\
\hline 3 & $\begin{array}{l}\text { Hukum } \\
\text { Kekekalan } \\
\text { Momentum }\end{array}$ & $\begin{array}{l}\text { Verifikasi } \\
\text { Hukum } \\
\text { Kekekalan } \\
\text { Momentum }\end{array}$ & $\begin{array}{l}\text { Modul } \\
\text { Momentum }\end{array}$ & $\begin{array}{l}\text { Sistem } \\
\text { VBL } \\
\text { dengan } \\
\text { Tracker } \\
\text { dan } \\
\text { Spreadsheet }\end{array}$ \\
\hline 4 & $\begin{array}{l}\text { Gerak } \\
\text { Harmonik } \\
\text { Sederhana }\end{array}$ & $\begin{array}{l}\text { Verifikasi } \\
\text { Energitika } \\
\text { Gerak } \\
\text { Harmonik } \\
\text { Sederhana } \\
\text { (GHS) }\end{array}$ & $\begin{array}{l}\text { Modul } \\
\text { GHS } \\
\text { (Pendulum) }\end{array}$ & $\begin{array}{l}\text { Sistem } \\
\text { VBL } \\
\text { dengan } \\
\text { Tracker } \\
\text { dan } \\
\text { Spreadsheet }\end{array}$ \\
\hline
\end{tabular}

Pada tahap perencanaan (plan) dilakukan identifikasi masalah yang ada di kelas yang akan digunakan untuk kegiatan lesson study dan perencanaan alternatif pemecahannya. Identifikasi masalah dalam rangka perencanaan pemecahan masalah tersebut berkaitan dengan karakteristik mahasiswa, suasana kelas, penyiapan Perangkat Eksperimen Fisika, rencana pelaksanaan pembelajaran dan evaluasi menggunakan soal pre tes dan pos test.

Pada tahap implementasi pembelajaran, dosen model yang telah disepakati, melakukan implementasi Satuan Acara Perkuliahan (SAP). Dosen lain melakukan observasi menggunakan lembar observasi yang telah dipersiapkan. Para observer ini mencatat hal-hal positif dan negatif dalam proses pembelajaran, terutama dilihat dari sikap mahasiswa dalam hal kerja kelompkok. Dalam implementasi ini dilakukan rekaman video (audio visual) yang meng-close-up kejadian-kejadian khusus pada dosen dan mahasiswa selama pelaksanaan pembelajaran. Hasil rekaman ini sebagai bukti autentik kejadian-kejadian yang didiskusikan dalam tahap refleksi.

Selesai praktik pembelajaran dilakukan refleksi. Pada tahap refleksi ini, dosen model dan para observer mengadakan diskusi tentang pembelajaran yang baru saja dilakukan. Pertama dosen model yang melakukan implementasi SAP diberi kesempatan untuk menyatakan kesan-kesannya selama melaksanakan pembelajaran. Selanjutnya observer menyampaikan hasil analisis data observasinya. Selanjutnya, dosen yang melakukan implementasi tersebut memberikan tanggapan balik atas komentar para observer. Jika belum ada kesesuaian disampaikan misalnya, metode pembelajarannya, materi dalam LKS, media atau alat peraga, atau lainnya. Pertimbangan-pertimbangan ini digunakan untuk perbaikan rencana pembelajaran selanjutnya.

Sebagai indikator adanya peningkatan hasil pembelajaran pada mahasiswa akan dilihat pada aspek penguasaan pengetahuan koseptual, sikap, dan keterampialan (skill). Aspek pengetahuan konseptual diukur melalui test konseptual tertulis berbentuk tes objektif dan esai sesuai materi setiap siklusnya. Sedangkan penilaian keterampilan dilakukan melalui makalah dan paper dari setiap topik eksperimen. Aspek sikap mahasiswa diukur dari lembar observasi ketika dilakukan see.

\section{Hasil dan Pembahasan}

Pada Tabel 2 ditunjukan data hasil penelitian. Hasil evaluasi konseptual menunjukkan peningkatan dilihat dari hasil pre test dan post test. Bila dilihat dari hasil pre test kemampuan mahasiswa masih lemah untuk setiap siklusnya akan tetapi setelah proses pembelajaran menunjukan peningkatan pemahaman konseptual. Penggunan media 
VBL dan SBL memudahkan mahasiwa dalam memahami konsep fisika.

Tabel 2. Data Hasil Penelitian

\begin{tabular}{|l|l|l|l|l|l|l|l|l|}
\hline Kategori & \multicolumn{2}{|l|}{ Silus I } & \multicolumn{2}{l|}{ Siklus 2 } & \multicolumn{2}{l|}{ Siklus 3 } & \multicolumn{2}{l|}{ Siklus 4 } \\
\hline $\begin{array}{l}\text { Keteram- } \\
\text { pilan }\end{array}$ & \multicolumn{2}{|l|}{62,37} & \multicolumn{2}{l|}{65,13} & \multicolumn{2}{l|}{75,34} & \multicolumn{2}{l|}{78,22} \\
\hline $\begin{array}{l}\text { Konsep- } \\
\text { tual }\end{array}$ & Pre & Pos & Pre & Pos & Pre & Pos & Pre & Pos \\
\cline { 2 - 9 } & 65,4 & 73,5 & 65,4 & 89,7 & 64,9 & 79,2 & 79,2 & 89,7 \\
\hline
\end{tabular}

Hasil evaluasi keterampilan pada Siklus I penggunan simulasi PhET, mahasiswa masih belum lancar dalam penggunan simulasi terlihat masih banyak mahasiswa masih belum selesai dalam pengambilan data hal ini karena mahasiswa masih kesulitan dalam menenetukan $V_{\text {stop }}$ pada PhET.

Pada siklus II masih menggunakan simulasi PhET, karena merupakan penggunaan yang kedua mahasiswa lebih bisa mengeksplorasi simulasi yang diberikan akan tetapi ada beberapa mahasiswa yang masih kesulitan dalam merangkai rangkaian watak lampu pijar pada $\mathrm{PhET}$.

Pada siklus III yang merupakan pertama kalinya penggunaan VBL dan Laptop mahasiwa masih terlihat kebingungan menggunakan program tracker. Pada siklus IV yang merupakan kedua kalinya penggunaan VBL mahasiwa terlihat lebih lancar dalam penggunaannya, walaupun masih ada beberapa mahasiwa terlihat kebingungan dalam melakukan tracking data

Hasil observasi mengenai sikap mahasiswa yang ditinjau dari kerja kelompok dimasing-masing kelompok menunjukan peningkatan dari setiap siklusnya, walaupun setiap perubahan penggunan media pembelajaran kerja kelompok di masing-masing kelompok belum berjalan dengan baik, dilihat masih ada kelompok yang berdiskusi dengan kelompok lain. Hal ini terjadi karena penguasan perangkat eksperimen antar mahasiswa masih belum sama dan pembentukan kelompok yang belum efektif.

Untuk melatih keterampilan eksperimental berbasis multimedia dengan keterbatasan perangkat eksperimen diatasi dengan memberikan tugas kelompok diluar jam kuliah.

Penilaian terhadap kemampuan menyusun makalah dan poster ilmiah (dengan menggunakan tiga katagori cukup, baik, dan sangat baik) diperoleh kemampuan rata-rata mahasiswa dalam kategori baik.

\section{Kesimpulan}

Berdasarkan hasil penelitian, dapat disimpulkan bahwa pembelajaran berbasis lesson study pada mata kuliah eksperimen fisika menggunakan VBL dan SBL dapat meningkatkan kemampuan konseptual dan keterampilan mahasiswa.

\section{Ucapan Terima Kasih}

Terima kasih penulis ucapkan kepada semua pihak yang telah membantu dalam penelitian ini.

\section{Kepustakaan}

Gamboa, F., et al., 1999. Specification and Development of A Physics Video Based Laboratory. Intrumentation and Development Vol.4 Nr. 5.

Jaya, H. dan Haryoko, S. 2010, Pengembangan Laboratorium Virtual di SMK Untuk Meningkatkan Kompetensi Siswa Pada Mata Pelajaran Produktif. Makalah disajikan dalam Seminar Nasional Pendidikan Teknologi dan Kejurusan. Tanggal II Desember 2010. Surabaya:UNESA.

Mulyana, Slamet. 2008. Dampak Pendidikan Dan Pelatihan Lesson Study Terhadap Dosen-Dosen. Artikel Hasil Penelitian. LPMP Jawa Barat.

Mustikasari, A. 2008. Menuju Dosen Yang Profesional Melalui Lesson Study. Semarang. http://eduarticles.com/menuju-dosen-yang-profesional-melauilesson-study/. September 2008.

Prasetyo,S. 2012, Implementasi VBL Bagi Pembelajaran Fisika http://septiardiprasetyo.blogspot.com/2012/04/implementasi-vblbagi-pembelajaran.html. diakses tanggal 29 November 2012 jam I2.54.

Redish, E.F. I993. What Can a Physics Teacher Do with a Computer?.

http://www.physics.umd.edu/perg/papers/redish/resn ick.html. diakses tgl 29 Nov 2012 jam I3.25.

Resmiyanto, R. 2009. PhET: Simulasi Fisika untuk Membantu Pembelajaran di Kelas. http://rachmadresmi.blogspot.com/2009/03/phetsimulasi-fisika-untuk-membantu.html. diakses tanggal 29 November 2012 jam I2.23.

Sudrajat, A. 2008. Lesson Study untuk Meningkatkan Pembelajaran

http://akhmadsudrajat.wordpress.com/2008/02/22/1 esson-study-untuk-meningkatkan-pembelajaran/ diakses tanggal 4 November 2012 jam I5.00.

Yusak, M. 2007. Lesson Study: Pengembangan Profesional Dosen Secara Berkelanjutan Berbasis Sekolah. Semarang: Bimbingan Teknik Dosen Bahasa IPA SMA Dinas Pendidikan Kota Semarang. 